DOI: $10.20472 / \mathrm{TE} .2017 .5 .2 .002$

\title{
EDUCATION QUALITY PERCEPTION BY HIGHER EDUCATION INSTITUTION STUDENTS: EMPIRICAL FINDINGS
}

\section{LEV FISHMAN, OLGA TSIBINA}

\begin{abstract}
:
This paper presents certain findings of empirical study of students' perception of the education services quality in higher education institutions; it is shown that the majority of education services production quality parameters are irrelevant for students and might not lead to increasing the services quality as perceived by students. In other words virtually irrelevant for students is a whole range of education services quality characteristics, researchers and government oversight authorities in the education sphere pay special attention to.
\end{abstract}

\section{Keywords:}

education services, education services quality, quality of higher education

JEL Classification: A23

\section{Authors:}

LEV FISHMAN, Samara state pedagogical university, Russian Federation, Email: mi.ivanov@seznam.cz

OLGA TSIBINA, Samara state pedagogical university, Russian Federation, Email: m.ivanov@pgsga.ru

\section{Citation:}

LEV FISHMAN, OLGA TSIBINA (2017). EDUCATION QUALITY PERCEPTION BY HIGHER EDUCATION INSTITUTION STUDENTS: EMPIRICAL FINDINGS. International Journal of Teaching and Education, Vol. $\mathrm{V}(2)$, pp. 22-31., 10.20472/TE.2017.5.2.002 


\section{Research Design}

The higher vocational education subsystem is one of the large-scale services provision spheres; consequently, the issues of the respective services quality improvement are a major focus of attention of numerous researchers in Russia and abroad. However, different researchers - specifically, as applied to the mentioned education subsystem treat the notion 'education services quality' - rather differently. Over the last two decades, one of the authors of this paper developed the education services quality concept, methodology and techniques of the respective services quality management followed by a number of publications (e.g., Fishman, 2009).

This concept is based on fundamental ideas of many researchers (in particular, contained in the publications: Feigenbaum, 1961, Gronroos, 1982, Harrington, 1986, McDougall and Levesque, 2000, Mittal and Lassar, 1998, Pankrukhin, 1997, Stiglitz, 2000, Subetto, 2004, Walton, 1991), but is not limited to them. The primary target of this concept is the necessity of recognizing the education service (a university or school program can be an example of education service) as a category, characterizing its properties in relation to the external environment, and quality of its production in a given educational organization or education system described via the organization's or system's internal parameters pattern. The concept also implies segregation of the 'education service consumer-oriented quality' characterized by the delivery results and conditions of the process of its delivery that are important for the customers and consumers (e.g. students, their parents etc.). Other parameters (alongside with the 'consumer-oriented quality' characteristics) might include long-term effects of the services delivery and organizing educational resources, provided that these characteristics must be of interest primarily for the federal and municipal governance bodies as well as for constitutors of abovementioned institutions and not for the direct services producers (including institutional ones).

Regardless of the detected productivity of the abovementioned ideas in the education services production quality management in various institutions and subsystems, the concept in question needed to be additionally put to an evaluation test within the framework of higher vocational education. So, the main goal of the research described in the paper was to experimentally test the concept of education services quality.

In 2014-2015, we performed such an additional evaluation for the case of implementation of the main bachelor degree course curriculum - by means of collecting and analyzing empirical data on requirements of students trained in accordance with the Federal State Standards of this education level; emphasis was made on the consumer-oriented quality of the higher education institution's education services. The evaluation test purpose was identification of distinctions between the students' factual requirements with regard to the education consumer quality and the services quality characteristics used in everyday practice (including the state education quality control implementation procedures).

The study was conducted at four departments of the Povolzhye State Social-Humanities 


\section{Academy (hereinafter abbreviated as PGSGA).}

At the empirical study first stage, focus groups were employed; the intention was to involve these groups with the aim of forming a set of different characteristics of the education service quality being of interest for students-consumers. The focus groups were formed according to the homogeneity principle (by age and kind of activity) from among students of different years of study of all the departments involved. The conducted focus group discussions helped to create an aggregate picture of the education services quality characteristics of the higher vocational education much-indemand by students, define concretely the set of consumer properties of the given quality, which are important and meaningful for the users and which are satisfied in the process of the education service delivery. This being so (which seems to be important), the education service quality characteristics were defined not in customary for the education institutions faculty and administration terms, but in terms of the end consumers' requirements.

As a result of the focus groups sessions, definite education service quality characteristics were obtained - to be understood as special requirements (stated by the focus groups members) - satisfying of which influences the education service consumer perception entirely as being of high quality.

Based on analyzing results obtained within the framework of facilitating focus groups, a questionnaire was developed suggesting in particular ranking of representative number of students in terms of education services quality characteristics relevant for them. For this purpose, wordings proposed in the course of the focus group sessions were corrected in a minimum way (relatively equal characteristics were integrated in order to develop a general ranking list having not more than 20 ranking parameters; further, for some characteristics' definitions were completed - with the objective of excluding occurrence of antagonistic or ambiguous positions in one and the same line). The questionnaire-based survey also implied ascertainment of students' opinions about the education services actual quality (results of this part of study are not provided in this paper). We developed a questionnaire, which was tried out in a small respondents group - to ensure validity.

In the first part of the questionnaire, the students had to rank in descending order the education service quality characteristics important for them, i.e., what they conceive 'ideally', while in the second part of the questionnaire they had to assess per ten-point scale implementation of the proposed quality characteristics at their department. The number of proposed education service characteristics (20 in number) was well considered: firstly, our intention was to reflect the focus group work findings to the fullest extent possible and not to miss whenever appropriate not a single characteristic relevant for consumers; secondly, it was conditioned by the respondents' habitualness to decimal-type presentation of numerical information.

It should be noted (in our opinion, it is extremely important), that of 20 positions only one (and then only, indirectly) characterizes the educational results, the rest describe 
various features of the services delivery process. Indeed, only 'practice oriented training' can be linked to the training results (solely and exclusively via expected effects), other positions - typical process characteristics.

\section{Main Findings}

Let us proceed now to the ranking by respondents of the education services quality characteristics results as such, which are provided in Table 1.

Standard deviation shows that the collected data (significance assessments) are equally indiscreet concerning the mean one, which enables accurate comparisons. Slightly bigger assessments disagreement is observed as per alternative 7 , the highest shared understanding in answers - as per position 10, but these disagreements are not too large, being within the limits of $4.5-6$ points relative to the 20 -point scale.

Table 1 Education service quality characteristics ranking by respondents

\begin{tabular}{|c|c|c|}
\hline $\begin{array}{l}\text { Mean score of } \\
\text { significance } \\
\text { rating }\end{array}$ & $\begin{array}{c}\text { Mean score } \\
\text { ranking }\end{array}$ & Education service quality characteristics \\
\hline 8.73 & 5 & 1. Practice oriented training \\
\hline 8.32 & 3 & $\begin{array}{l}\text { 2. Employment assistance by the higher education } \\
\text { institution }\end{array}$ \\
\hline 6.36 & 2 & $\begin{array}{l}\text { 3. Ability of faculty members to find some common } \\
\text { ground with the students and goodwill on the Dean's } \\
\text { Office part }\end{array}$ \\
\hline 8.41 & 4 & $\begin{array}{l}\text { 4. Well-defined structure of the specified requirements } \\
\text { and transparency of students' performance } \\
\text { assessment }\end{array}$ \\
\hline 10.89 & 11 & $\begin{array}{l}\text { 5. Location of the academic building (possibility of } \\
\text { getting to the training premises by public transport) }\end{array}$ \\
\hline 11.03 & 13 & 6. Image of higher education institution \\
\hline 13.69 & 19 & $\begin{array}{l}\text { 7. Availability of student hostel not far from the } \\
\text { academic building }\end{array}$ \\
\hline 10.18 & 7 & $\begin{array}{l}\text { 8. Good facilities and resources (modern maintenance, } \\
\text { convenient furniture, availability of technical } \\
\text { teaching aids) }\end{array}$ \\
\hline
\end{tabular}




\begin{tabular}{|c|c|c|}
\hline 10.55 & 9 & $\begin{array}{l}\text { 9. Developed infrastructure (availability of good } \\
\text { canteen, playgrounds, parking place, campus, } \\
\text { library accessibility, opportunity of using Wi-Fi) }\end{array}$ \\
\hline 5.43 & 1 & $\begin{array}{l}\text { 10. High competence of the faculty members in } \\
\text { presenting educational material }\end{array}$ \\
\hline 12.15 & 16 & 11. Absence of bribes in the training process \\
\hline 9.20 & 6 & $\begin{array}{l}\text { 12. Convenience of the teaching agenda and absence } \\
\text { of failures in it }\end{array}$ \\
\hline 10.57 & 10 & 13. Possibility for students to combine studies and work \\
\hline 11.26 & 14 & $\begin{array}{l}\text { 14. Opportunity for students to realize their potential in } \\
\text { different fields (in creative work and public life) }\end{array}$ \\
\hline 10,27 & 8 & 15. Providing students with interning facilities \\
\hline 13.14 & 18 & 16. Academic degrees and titles of the faculty members \\
\hline 13,89 & 20 & 17. Active research activity of the faculty members \\
\hline 12.00 & 15 & $\begin{array}{l}\text { 18. Availability of syllabuses and resource materials in } \\
\text { the academic courses }\end{array}$ \\
\hline 12.93 & 17 & 19. Possibility for students to do research \\
\hline 11.01 & 12 & 20. Organizing internship and training abroad \\
\hline
\end{tabular}

As it can be seen from the Table, the most relevant education service quality characteristic (as perceived by the students) is high competence of the faculty members in presenting educational material, second best feature - ability of the faculty to find some common ground with the students and goodwill on the Dean's Office part, on the third place - employment assistance by the higher education institution, ... lastly active research activity of the teachers.

In other words, traditional production characteristics of the education service quality regularly assessed by the education institutions' administrators with the purpose of improving the education process quality - such as possibility for students to do research, academic degrees and titles of the faculty members, active research activity of the faculty members - are not among the important and relevant features of the education service quality.

Contrariwise, education service consumers consider important such education service quality characteristics that are usually not analyzed by the administrators and are 
disregarded by them. These characteristics include ability of the faculty to find some common ground with the students and goodwill on the Dean's Office part, convenience of the teaching agenda and absence of failures in it, adequate facilities and resources and developed infrastructure of the higher education institution (availability of good canteen, playgrounds, parking place, campus, library accessibility, opportunity of using Wi-Fi).

The list of priority-driven characteristics also include components that are traditionally in the limelight of the administrative staff - employment assistance by the higher education institution, well-defined structure of the specified requirements and transparency of students' performance assessment, practice oriented training.

However, the first place as per relevance for students is taken by the high competence of the faculty members in presenting educational material, while this competence is usually ignored by the higher education institution administration, and it is checked in no way. It is sufficient for the faculty member to develop a steering curriculum document in compliance with formal requirements and some other documents, and there is nothing more to it. Moreover, higher education institution administration doesn't care about his/her conduct in class when students attend seminars or lectures and about the manner of presenting the educational material. Formulated differently, administrators regard as important formal provision of the education process quality (developed per necessary format teaching package, assessment means set and other formal papers), while the education service consumer attach importance to informal provision of the delivered education service quality, i.e., proficiency of the teachers in explaining respective material. This being so, one might assume that the paperwork disturbs the faculty members from their true-life work, from real-life communication with students, which they put on the first place in ranking the education service quality characteristics. In other words, it is irrelevant for the education service consumer to what extent the faculty member completed the formal paperwork; the consumer lays emphasis on communication with the lecturers and the Dean's Office staff, face-to-face contact (within the framework of the academic module and beyond it)! Along with this, in our opinion, there exists visible linkage between the correctly filled in point-rating card and ability of presenting the educational material in a comprehensible manner, which follows from the importance for students of a well-defined structure of the specified requirements and transparency of students' performance assessment.

In order of importance for students, it is possible to differentiate visually several groups of characteristics.

The most important higher education service characteristics are 10 and 3; these are requirements as to high competence of the faculty members in presenting educational material as well as to communication of the lecturers and the Dean's Office staff with students.

The next in order of importance group - 2, 4, 1, 12 - is related to the training process content and organization (practice oriented training, well-defined structure of the 
specified requirements and transparency of students' performance assessment, convenience of the teaching agenda and absence of failures in it) as well as students' employment assistance by the higher education institution.

The next characteristics group is related to the university's facilities and resources and infrastructure, provision with interning facilities and possibility of combining studies and work - 8, 15, 9, and 13.

The group of the education service characteristics (relevant for the consumers) is closed by features linked to the university's image, organizing internship and training abroad, convenient location of training premises and opportunity of realizing personal potential in different fields $-5,20,6$, and 14 .

Analysis of histograms indicated that the responses distribution character is not uniform. Some are shifted to the right, others - to the left, available are bimodal and even trimodal ones. However, there is not a single one more or less resembling standardized distribution. This can be accounted for by degree of relevancy of the respective education service from students' point of view; they have their own opinion about the education service quality characteristics, they also responsibly take the ranking in their responses. Thereby, the respondent students group is non-uniform in their assessments.

Here, find provisions of results of the performed hierarchical cluster analysis with regard to the education service characteristics.

Statistical methods enable evaluation of proximity measure of the scheduled by us characteristics as to students' responses. In other words, if characteristics from question 1 often lead to similar responses as to the ranks values, most likely they are perceived as close ('similar', 'in line') service's characteristics. The cluster analysis 'compresses' data into the objects' classification. The cluster analysis implies determination of intervals between observations (in our case - characteristics as per question 1) of the objects set; the cluster analysis algorithms are formulated in terms of intervals.

This method implements the hierarchical agglomerative algorithm. Its meaning involves the following. Prior to clusterization, all the objects are regarded as separate clusters aggregated in the course of the algorithm implementation. At first, a pair of nearest clusters is selected, which are then aggregated in one cluster. As a result, the number of clusters goes to $\mathrm{N}-1$. The procedure is repeated, until all the clusters are aggregated. Aggregation can be interrupted at any stage, thus producing the necessary number of clusters. Consequently, results of the aggregation algorithm operation determine techniques of calculating intervals between objects and determining proximity between clusters.

Proximity measure - correlation coefficient, is based on calculating interval between variables. Euclidean distance and its square are feasibly applicable for analyzing quantitative data.

Analysis showed that it is possible to single out 4 clusters characterizing different sides 
of education service and reflecting different relevance for students.

The first cluster is characterized by the following components:

- Academic degrees and titles of the faculty members

- Active research activity of the faculty members

- Availability of syllabuses and resource materials in the academic courses

- Possibility for students to do research

- Organizing internship and training abroad

- Opportunity for students to realize their potential in different fields (in creative work and public life)

- Absence of bribes in the training process

This cluster incorporated characteristics, which in terms of significance was put on the last rating places by consumers; these characteristics are effectively irrelevant for students. Consequently, this characteristics group is predominantly linked to formal provision of the education process (while students lay much more emphasis on informal, 'live' communication), is important though for the university's accreditation indicators, various non-governmental curriculum monitoring types, etc. In other words, it is irrelevant for a student, whether he or she is instructed by a professor, by a senior lecturer or assistant, whether the teacher published significant number of papers and guidance materials, they are not scared by occurrence/absence of bribes in education, consumers of the education services pay attention to other things. (Truly speaking, one more factor should be noted here. The fact that absence of bribery is of no critical importance for the PGSGA students most probably indicates that they just do not really encounter bribes, which prove the second questionnaire point analysis results.) This notion can be also rendered differently: the mentioned characteristics can be addressed (or not addressed) in the capacity of the education service production quality; however, they are not considered by the majority of students as independent values; therefore, predominantly they are not characteristics of the education services consumer quality in THIS HIGHER EDUCATION INSTITUTION and for THESE students.

\section{Below, are the components of the second cluster:}

- Possibility for students to combine studies and work

- Providing students with interning facilities

- Convenience of the teaching agenda and absence of failures in it

- Good facilities and resources (modern maintenance, convenient furniture, availability of technical teaching aids)

- Developed infrastructure (availability of good canteen, playgrounds, parking place, campus, library accessibility, opportunity of using Wi-Fi)

- Location of the academic building (possibility of getting to the training premises by public transport)

- Image of higher education institution

In other words, these are characteristics linked to the university infrastructure maturity, facilities and resources used in the teaching and learning activities (convenient 
timetable, modern maintenance, study aids) as well as opportunity of having side job and undertake internship. These characteristics are rather important for students.

The third cluster includes the following features:

- Ability of faculty members to find some common ground with the students and goodwill on the Dean's Office part

- High competence of the faculty members in presenting educational material

- Well-defined structure of the specified requirements and transparency of students' performance assessment

- Practice oriented training

- Employment assistance by the higher education institution

The students put all the above characteristics on the highest priority positions. This characteristics group, linked to communication between the faculty members and department administration and the students, mediately reflecting requirements with regard to the education process and the content-specific side of its organization, is the most important one for the education services consumers.

\section{The fourth cluster:}

- Availability of student hostel not far from the academic building

This is definitely a separate characteristic, which on average the students put on the next to last place in terms of priority. The students do not perceive it as being close to any other characteristic. The abovementioned analysis results lead to understanding that the education services consumers shaped a wide scatter of opinions of this characteristic significance; we also found out that it is of higher priority for village students and students from smaller towns. It is understandable enough, as this characteristic is rather specific and relevant only for residents of other cities, while it is of no importance for local students from the point of view of delivering education service; consequently, they cannot regard this characteristic as part of the university infrastructure, which they perceive a bit differently (availability of good canteen, playgrounds, parking place, campus, library accessibility, opportunity of using Wi-Fi).

\section{Main Conclusions}

Although some of the education services characteristics (the rank of which was studied in the questionnaire survey) relevant for students that were detected in working with focus groups, are linked to the results of delivering education services and even to the long-term effect of their delivery, the direct consumers perceive as significant values only conditions of delivering education services.

It is also important to emphasize that virtually irrelevant for consumers is a whole range of education services quality characteristics, researchers and government oversight authorities in the education sphere pay special attention to, while administration of education institutions allocates resources to maintain the respective characteristics: 
strict abidance by requirements of the State Educational Standard, regulatory licenserelated compliance as to availability of course books and training floor space, formal qualification of pedagogical human resources, quality of training documentation.

This situation is an evidence of productivity of the approaches developed by us, within the framework of which the education services quality is under consideration in two interrelated but principally divergent aspects. Specifically, eventual users do not view or scarcely view as characteristics of the education services quality the categories attributed to the second aspect: categories of the service production quality in a particular education organization or education system. That means that a whole range of parameters of the education services production quality undoubtedly develops important production environment as to ensuring the education service quality in reference to the education organizations' and education systems' external environment. However, these are conditions that might lead but might not lead to improving the service quality as perceived by external parties.

\section{References}

Feigenbaum A. V. 2004. Total Quality Control, McGraw-Hill. 896 p. ISBN 978-0070220034.

Fishman L. 2009. Metodologiya i mekhanizmy povysheniya kachestva obrazovatel'nykh uslug na osnove delegirovaniaya obratnykh svyazii. Samara: Nauchnyi centr RAN. 197 s. ISBN 978-5-93424-4423.

Gronroos Ch. 1982. Strategic management and marketing on the service sector. Swedish School of Economics and Business Administration. 222 p. ISBN 978-9515551672.

Harrington H. J. 1987. The Improvement Process: How America's Leading Companies Improve Quality. New York: McGraw-Hill. 284 p. ISBN 9780071004770.

McDougall G.H.G., Levesque T. 2000. Customer Satisfaction with services: putting perceived value into equation. Journal of Services Marketing, vol. 14, no. 5, p. 392-410. ISSN 0887-6045.

Mittal B., Lassar W.M. 1998. Why do customers switch? The dynamics of satisfaction versus loyalty. Journal of Services Marketing, vol. 12, no. 3, pp. 177-194. ISSN 0887-6045.

Pankrukhin A. 1997. Marketing obrazovatel'nykh uslug. Marketing v Rossii i za rubezhom, vol. 7, pp. 7985. ISSN 1028-5849.

Stiglitz J.E. 2000. Economics of the public sector. New York: W.W. Norton \& Company. 960 p. ISBN 9780-393-92522-7.

Walton M. 1991. Deming Management at Work. New York, N. Y.: Perigee Books. 249 p. ISBN 9780399516856. 